\title{
Proteolysis in microfluidic droplets: an approach to interface protein separation and peptide mass spectrometry $\dagger$
}

\author{
Ji Ji, $\uparrow^{a}$ Lei Nie, $\leftarrow^{a}$ Liang Qiao, ${ }^{b}$ Yixin Li, ${ }^{a}$ Liping Guo, ${ }^{a}$ Baohong Liu, ${ }^{* a}$ Pengyuan Yang*a and \\ Hubert H. Girault ${ }^{b}$
}

Received 25th February 2012, Accepted 1st May 2012

DOI: $10.1039 / \mathrm{c} 2 \mathrm{lc40206h}$

\begin{abstract}
A versatile microreactor protocol based on microfluidic droplets has been developed for on-line protein digestion. Proteins separated by liquid chromatography are fractionated in water-in-oil droplets and digested in sequence. The microfluidic reactor acts also as an electrospray ionization emitter for mass spectrometry analysis of the peptides produced in the individual droplets. Each droplet is an enzymatic microreaction unit with efficient proteolysis due to rapid mixing, enhanced mass transfer and automated handling. This droplet approach eliminates sample loss, cross-contamination, nonspecific absorption and memory effect. A protein mixture was successfully identified using the droplet-based micro-reactor as interface between reverse phase liquid chromatography and mass spectrometry.
\end{abstract}

During the last decade, two approaches have been developed for proteomics research: top-down and bottom-up. Among the various strategies, shotgun proteomics has been widely used because of its high throughput and automation. The complex samples are enzymatically digested and then separated by high performance liquid chromatography (HPLC), before being analysed by mass spectrometry (MS) for sequencing via database searching. ${ }^{1-4}$ However, it is difficult to achieve the simultaneous digestion of large amount of proteins, the separation of thousands peptides and data processing for accurate protein identification. Peptides from high-abundance proteins may undermine the detection of those from low-abundance ones. ${ }^{4}$ Therefore, if the protein mixture is completely pre-separated, where a simple protein component is found in each fraction, and followed with in situ digestion, more detailed information about protein sequence and post-translational modification would be obtained.

${ }^{a}$ Department of Chemistry, Institute of Biomedical Sciences and State Key Lab of Molecular Engineering of Polymers, Fudan University, Shanghai,200433, China.E-mail: bhliu@fudan.edu.cn:

pyyang@fudan.edu.cn; Fax: +86 21 65641740; Tel: +86 2165642009

${ }^{5}$ Laboratoire d'Electrochimie Physique et Analytique, Ecole

Polytechnique Fédérale de Lausanne, CH-1015, Lausanne, Switzerland. E-mail: hubert.girault@epfl.ch; Fax: +41216933667;

Tel: +41216933145

$\uparrow$ Electronic Supplementary Information (ESI) available: Detailed experimental section. See DOI: 10.1039/c2lc40206h

$\$$ J. Ji and L. Nie contributed this work equally.
Recently, many strategies have been developed for proteomics through protein separation, such as Offgel electrophoresis, ${ }^{5}$ proteolysis, peptide separation and MS detection..$^{68}$ The development of integrated platforms to achieve automatic operation of the whole systems have been proposed for high throughput characterization of proteins. ${ }^{9,10}$ For example, Zhang et al. have established an integrated platform with the combination of protein separation by liquid chromatography (LC), on-line protein digestion by immobilized trypsin column, peptides separation and peptide identification by electrospray ionization mass spectrometry (ESIMS/MS) ${ }^{9}$

The immobilized trypsin has been demonstrated to be a highly efficient protocol for on-line digesting proteins. ${ }^{11-14}$ However, the micro-reactors have the drawback of non-specific absorption of proteins and peptides resulting in a memory effect, which hampers the large-scale proteome study. It is also difficult to collect fractions for storage and further protein characterization. Compartmentalization of effluents into droplets with microfluidic chip has emerged as a novel way to collect fractions from separation methods such as HPLC and CE. ${ }^{15,16}$ Droplet-based microfluidic technique offers an attractive alternative to conventional microfluidic chips based on continuous flow systems by performing chemical and biological reactions in picoliter to nanoliter volumes without dilution and cross-contamination. ${ }^{17-20}$ In essence, each droplet is analogous to a conventional reaction unit but with the advantages of the following: reduced reagent consumption, rapid mixing, enhanced diffusion, efficient heat and mass transfer, automated handling and continuous processing. ${ }^{21}$ Meanwhile, mass spectrometry is the most attractive analytical technique for the analysis of segmented flows, because it has the high sensitivity and speed for the analysis of low volume samples at high throughput. Recent advances in mass spectrometry ${ }^{22}$ and microfluidics ${ }^{23}$ have enabled integration of these tools to address the requirement of high-throughput protein analysis. ${ }^{24}$

Based on these ideas, we present a droplet-based microfluidic reactor for online tryptic digestion of proteins from HPLC fractions for the first time. The generated peptides were either collected for matrix-assisted laser desorption/ionization (MALDI) MS analysis or directly electro-sprayed from the outlet of the microchip for MS identification. In this way, the proposed droplet micro-reactor can be used as an interface between protein separation by liquid chromatography and peptide analysis by 
mass spectrometry. Such an integrated platform has been successfully applied for the analysis of a mixture of proteins.

A schematic illustration of the droplet-based protocol is shown in Fig. 1. The microfluidic device was fabricated following the softlithography technique, using polydimethylsiloxane (PDMS) as the base material. The general design and dimensions of the device are shown in Figure SI-1†. A covalent surface modification was carried out to obtain a stable hydrophobic coating on the PDMS microchannels. After plasma bonding, aquapel, a commercially available water repellent agent, was flushed through the device for a few seconds for the surface modification; the microchip was then baked at $65{ }^{\circ} \mathrm{C}$ for $20 \mathrm{~min} .{ }^{25}$ Protein sample (A), trypsin solution (B), oil (C) and $\mathrm{pH}$ regulating solution (D) were mixed from different inlets as shown in Fig. 1. The droplets were generated and the digestion reaction took place when the droplets travelled through the microchannels. All the reactions temperature was controlled at $37^{\circ} \mathrm{C}$. Here perfluorodecalin (PFD) was used as the oil phase since it is difficult to charge in a certain ionization voltage range in order to generate interference signals on MS. It is also biologically inert, showing no deleterious effect on the enzymatic reaction. ${ }^{26}$

Cytochrome- $c$ (Cyt-c) was firstly employed as a model protein to evaluate the effectiveness of the droplet microreactor. $10 \mathrm{ng} \mu \mathrm{L}^{-1}$ Cyt-c (in water), $1 \mathrm{ng} \mu \mathrm{L}^{-1}$ trypsin (in $40 \mathrm{mM}$ $\mathrm{NH}_{4} \mathrm{HCO}_{3}$ aqueous solution) and PFD were infused from inlets $\mathrm{A}, \mathrm{B}$ and $\mathrm{C}$ at flow rates of 120,120 and $300 \mu \mathrm{L} \mathrm{h}^{-1}$, respectively. Aqueous droplets $(\mathrm{pH}$ 8) were formed and digestion occurred rapidly in the droplets at $37{ }^{\circ} \mathrm{C}$ in $2 \mathrm{~min}$. At the end of the reaction channel, 1\% formic acid (FA) solution was injected at a flow rate of $200 \mu \mathrm{L} \mathrm{h}^{-1}$ to terminate enzymatic reaction and adjust buffer $\mathrm{pH}$ for MS analysis. ${ }^{27,28}$ The side channel (as shown in Fig. 1) was wetted with adjuster buffer firstly and every droplet could be fused with buffer at the selected flow rates. The effluents were collected and analyzed by MALDI-TOF-MS. 14 peptides were successfully identified in this droplet microchip, as shown in Fig. 2a, revealing the highly efficient enzymatic reaction of the microfluidic droplet reactor. The enhanced reaction rates could be attributed to the internal flow circulation within the droplets. ${ }^{18}$

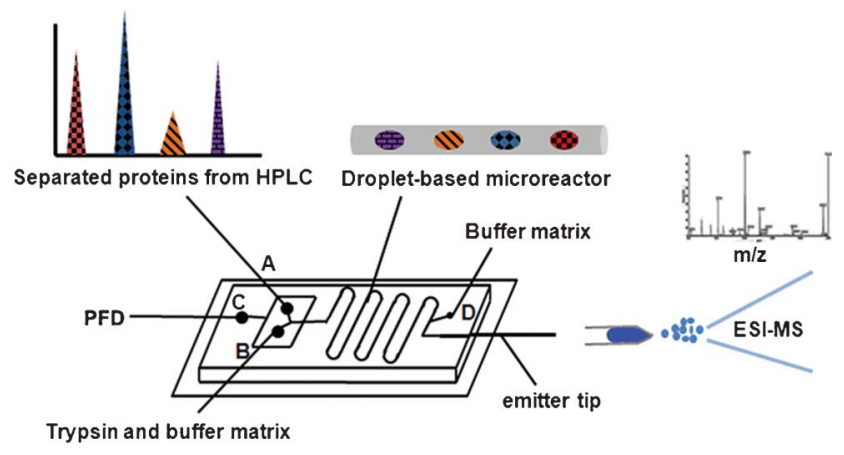

Fig. 1 Schematic presentation of the integrated platform for protein analysis, combining protein separation by HPLC, on-line digestion by a droplet-based microfluidic reactor, and protein identification by ESI-MS/ MS. The separated proteins were infused directly into the channel from inlet $\mathrm{A}$, trypsin was infused from the inlet $\mathrm{B}$ and the oil (PFD) was infused from inlet $\mathrm{C}$. The $\mathrm{pH}$ adjuster $(50 \% \mathrm{ACN} / 49 \%$ water/ $1 \% \mathrm{FA})$ was infused through the inlet $\mathrm{D}$.
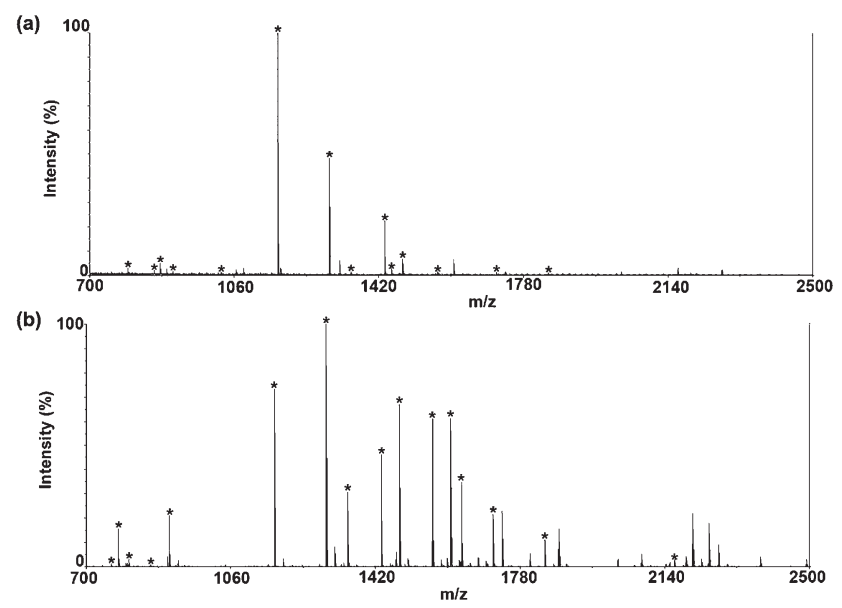

Fig. 2 MALDI-MS spectra of droplet digestion of Cyt- $c$. The digestion was performed in the microfluidic droplets by injecting $10 \mathrm{ng} \mu \mathrm{L}^{-1}$ Cyt- $c$ in a) water, or b) $9: 1 \mathrm{ACN}$ : water into the microchannel via inlet $\mathrm{A}$ at a flow rate of $120 \mu \mathrm{L} \mathrm{h}^{-1} .1 \mathrm{ng} \mu \mathrm{L}^{-1}$ trypsin in $60 \mathrm{mM} \mathrm{NH}_{4} \mathrm{HCO}_{3}$ aqueous solution at a flow rate of $120 \mu \mathrm{L} \mathrm{h}^{-1}$ was infused via inlet B. PFD was infused via inlet $\mathrm{C}$ at a flow rate of $300 \mu \mathrm{L} \mathrm{h}^{-1}$. Buffer of $50: 49: 1$ ACN : water : FA was infused via inlet D at a flow rate of $200 \mu \mathrm{L} \mathrm{h}{ }^{-1}$. * The identified peptides from Cyt- $c$.

Considering that protein fractions from reverse-phase liquid chromatography (RPLC) normally contain various concentrations of acetonitrile (ACN), ACN was added into the Cyt-c solution with different concentrations while keeping the other conditions constant to study the effect of organic solvents on the digestion efficiency. When the concentration of ACN in solution A was $50 \%$, corresponding to $25 \% \mathrm{ACN}$ in a droplet, 16 tryptic peptides were successfully identified. Even when the concentration of ACN in solution A was increased to $90 \%$, corresponding to $45 \% \mathrm{ACN}$ in a droplet, 16 peptides could still be identified (as shown in Fig. 2b). It was reported by Schriemer et al. that more efficient digestion can be obtained in the presence of $\mathrm{ACN}$ at a certain concentration. ${ }^{29}$ The mixed organic-aqueous conditions would favour a partial denaturation of proteins, therefore some previously inaccessible reaction sites in proteins are exposed for enzymatic cleavage. ${ }^{30}$ Results in Fig. 2 indicate that the digestion of proteins can be achieved within the droplet-based enzymatic reactor containing ACN up to $45 \%$.

Another outstanding feature of the droplet-based microchip is its compatibility with ESI-MS. In this work, a stainless steel needle with $250 \mu \mathrm{m}$ outer diameter and $100 \mu \mathrm{m}$ inner diameter was used as an ESI emitter. Based on the developed approaches for microchip droplets-ESI-MS analysis, ${ }^{26,31,32}$ the electrospray voltage was optimized with a series of aqueous samples of reserpine in immiscible oil, PFD, in full scan mode. The reserpine $\left(100 \mathrm{pg} \mu \mathrm{L}^{-1}\right.$ aqueous solution), reserpine (100 pg $\mathrm{LL}^{-1}$ aqueous solution) and PFD were infused into the inlets A, B and C at flow rates of 120 , 120 and $300 \mu \mathrm{L} \mathrm{h}^{-1}$, respectively (as shown in Fig. 1). When the ESI was performed at an ionization voltage of $2.0 \mathrm{kV}$, the total ion current (TIC) revealed that the signals of reserpine $(\mathrm{m} / \mathrm{z}$ 609.3) were detected from aqueous droplets but no signal was obtained from oil segments with the microchip droplets ESI-MS (as shown in Figure SI-2†). The oil phase formed droplets at the emitter, and then migrated along the outside of the tip away from the emitter, presumably by gravity and wetting. ${ }^{26}$ When the ionization voltage 
was increased, the TIC increased as well. However, the oil phase was sprayed when an ionization voltage higher than $2.0 \mathrm{kV}$ was used, which interfered with MS analysis. Therefore, optimal ESI voltage was determined to be around $2.0 \mathrm{kV}$ and used for the following experiments.

One of the main challenges of the integrated system is the compatibility of $\mathrm{pH}$ values and matrix buffers, since the optimal buffer solutions and $\mathrm{pH}$ values of various procedures are different: the ideal buffer solution for positive ESI should be a low $\mathrm{pH}$ aqueous solution containing at least $50 \%$ methanol or acetonitrile; the tryptic digestion of proteins should be performed under weak basic condition (i.e. $\mathrm{pH}$ 8.0); the protein fractions from RPLC are normally in a low $\mathrm{pH}$ aqueous solution containing FA or trifluoroacetic acid (TFA). Herein, we adjusted the $\mathrm{pH}$ of the solvents in the microfluidic chip for optimizing reactions and response signals. The protein solution (in 50:49.9: 0.1 ACN : water : FA), which has similar solvent properties as the fractions from RPLC, and the trypsin solution (in $60 \mathrm{mM}$ $\mathrm{NH}_{4} \mathrm{HCO}_{3}$ aqueous solution) were infused into inlets $\mathrm{A}$ and $\mathrm{B}$ at flow rates of 120 and $120 \mu \mathrm{L} \mathrm{h}^{-1}$, respectively. The $\mathrm{pH}$ value of the reaction in droplet was then 7.6 , suitable for tryptic reaction. To adjust the $\mathrm{pH}$ of droplet solution to a low value for well electrospray ionization, the $\mathrm{pH}$ adjuster was directly added to the droplet through a side channel from inlet D (Fig. 1) with an appropriate flow rate based on the previous research. ${ }^{27}$ It was reported that the neutralization of acid and alkali could be completed when the merged droplets proceeded through the short channel before emitter tip for few seconds. ${ }^{28}$ Herein, a buffer of $50: 49: 1$ ACN : water : FA was infused into the inlet $\mathrm{D}$ at a flow rate of $200 \mu \mathrm{L} \mathrm{h}^{-1}$ for altering the $\mathrm{pH}$ value to match electrospray ionization, where the effluent $\mathrm{pH}$ value was about 3.2. Using the above conditions, proteins could be digested on-line in the droplet-based microreactor and identified with the ESI-MS identification. As shown in Fig. 3, myoglobin (Myo, $100 \mathrm{ng} \mu \mathrm{L}^{-1}$ ) was identified with 9 peptides corresponding to an amino acid sequence coverage of $60 \%$. The detailed information of identified peptides was shown in Table SI- $1 \uparrow$. As a comparison, $100 \mathrm{ng} \mu \mathrm{L}^{-1}$ myoglobin was digested in solution for six hours. 15 peptides were observed and the amino acid sequence coverage was 71\% (Table SI- $2 \dagger$ ). Digestion of bovine serum albumin (BSA, $100 \mathrm{ng} \mu \mathrm{L}^{-1}$ ) was also performed and 5 peptides were identified using such droplet reactor (Figure SI-3† and Table SI-3†). These results demonstrate the potential of the present system used as an effective interface to collect HPLC fractions, avoiding cross-contamination between the droplets.

The final goal of this platform is to perform rapid online digestion, integrated with protein separation and peptide identification steps for automatic analysis of proteins. Separation methods can be RPLC using C4-C8 stationary phases in capillary columns, ${ }^{33}$ reverse-phase nonporous columns, ${ }^{34}$ or monolithic polymer columns. ${ }^{35}$ These methods are well recognized to be powerful for intact protein separation, providing numerous advantages including high resolution, high sensitivity, and effective coupling to mass spectrometry. To evaluate the performance of such a system, a three-protein mixture, including Myo, lysozyme and Cyt- $c$ was analyzed, and the results are shown in Fig. 4. Proteins were well separated into three fractions by RPLC, and each fraction was compartmentalized on-line into droplets that flowed in-sequence through the microchannel for online digestion

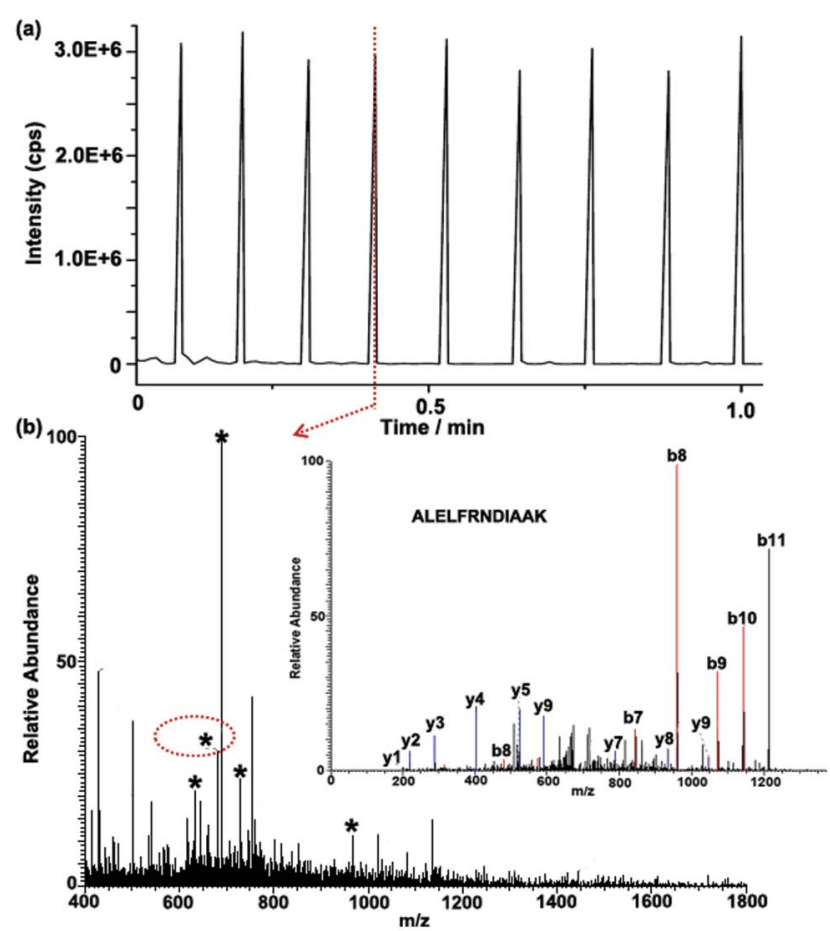

Fig. 3 a) The base peak chromatography of the on-line protein (100 ng $\mu \mathrm{L}^{-1}$ myoglobin) identification with the microfluidic reactorESI-MS/MS platform; b) The mass spectrum of myoglobin obtained from the apex of the peak indicated by dashed line in a); the insert is the ESIMS/MS spectrum of the peptide at $m / z=680.9$ Th with the sequence of ALELFRNDIAAK; $100 \mathrm{ng} \mu \mathrm{L}^{-1}$ myoglobin in $50: 49.9: 0.1$ ACN : water : FA at a flow rate of $120 \mu \mathrm{L} \mathrm{h}^{-1}$ was infused into the droplet-based microchip via inlet A, while the other conditions were same as those in Fig. 2. The ESI voltage was $2.0 \mathrm{kV}$. * The identified peptides from myoglobin.

and identification by ESI-MS/MS. By database query, all proteins, Cyt- $c$, Myo and lysozyme, were successfully identified with 13, 8 and 5 peptides, corresponding to amino acid sequence coverage of $67 \%, 61 \%$ and $53 \%$, respectively. The detailed peptide information was shown in Table SI-4 to Table SI-6†.

The system developed here incorporates a C4-based reversedphase liquid chromatography. However, other protein separation technologies could also be adapted. In this platform, no fraction collection is required for proteolysis because the digestion is on-line and in real-time. This would benefit automation and reduce sample loss, since all sample-handling steps are eliminated. Moreover, an integrated separation-digestion-ESI-MS/MS system would substantially reduce the analysis time associated with processing protein mixtures.

\section{Conclusions}

In this study, a droplet-based proteolysis reactor has been developed to fractionate proteins separated by HPLC for an online digestion, where the generated peptides are identified by ESIMS/MS. The effluent of separated proteins mixed with trypsin were distributed into nanoliter reactors by water-in-oil droplet and digested with high speed when flowing through the microchannel. No sample cross-contamination or memory effect was observed. The system performance could be further improved by employing 
(a)

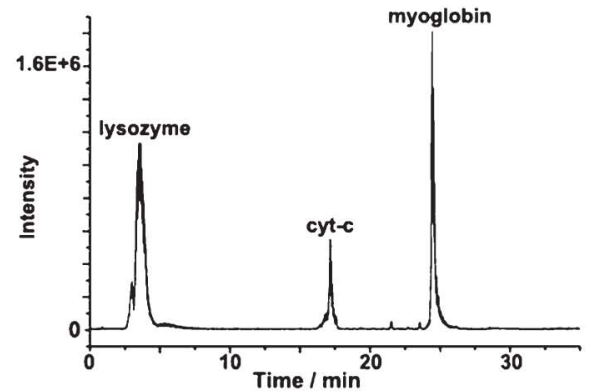

(b)
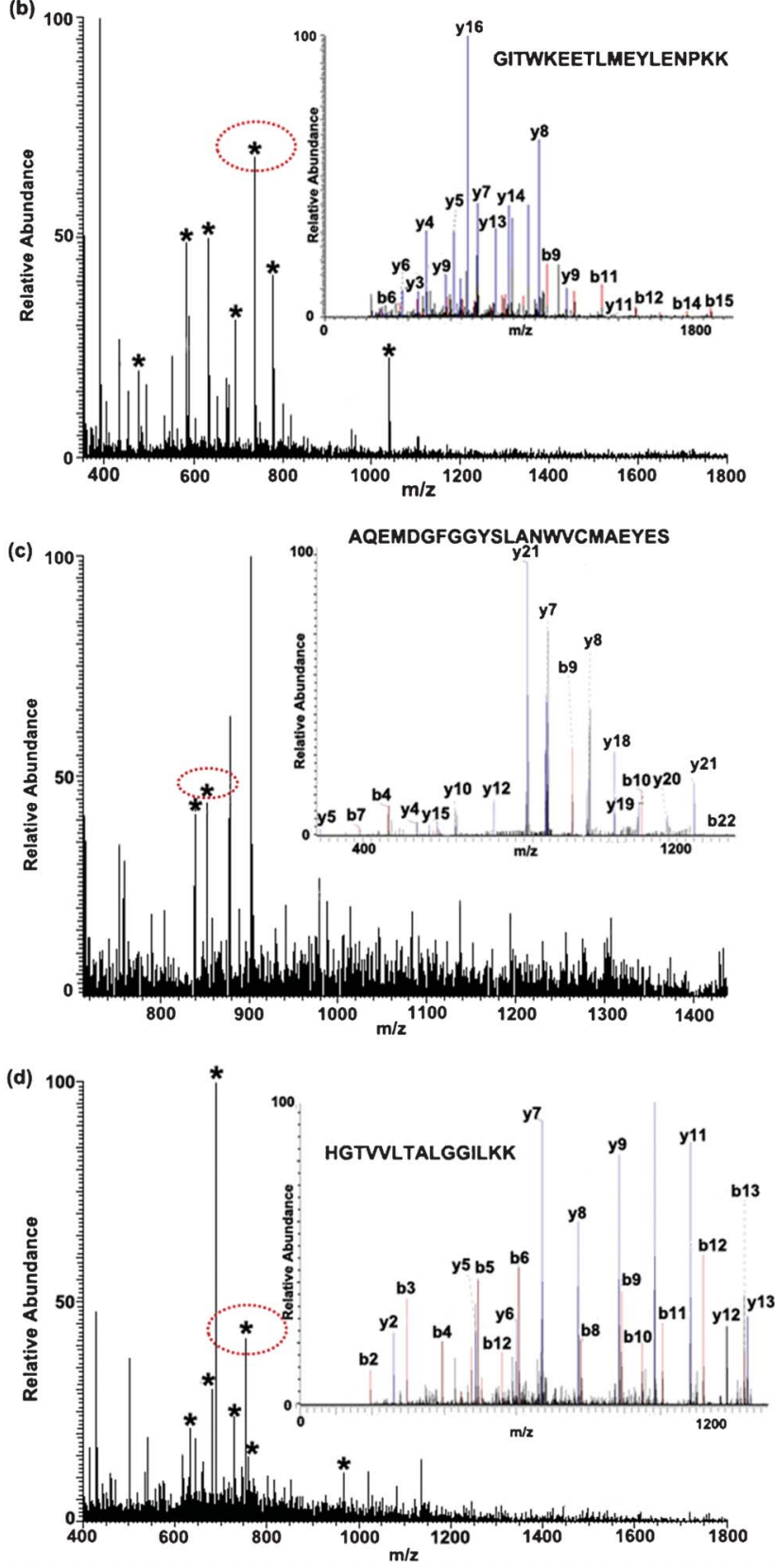

Fig. 4 a) Reverse phase separation of a mixture of three proteins $(0.13 \mu \mathrm{g}$ Cyt-c, $0.92 \mu \mathrm{g}$ lysozyme, and $0.16 \mu \mathrm{g}$ myoglobin) with MS detector. b) The mass spectrum of peptides from a fraction of Cyt- $c$ eluted at $\mathrm{RT}=17.8 \mathrm{~min}$. The insert is the ESI-MS/MS spectrum of a parent peak at $m / z=736.8 \mathrm{Th}$ with the sequence of GITWKEETLMEYLENPKK. $\mathrm{c}$ ) The mass spectrum of peptides from a fraction of Lysozyme eluted at RT
$=4.65 \mathrm{~min}$. The insert is the ESI-MS/MS spectrum of a parent peak at $\mathrm{m} / \mathrm{z}=$ 852.6 Th with the sequence of AQEMDGFGGYSLANWVCMAEYES. d) The mass spectrum of peptides from a fraction of myoglobin eluted at $\mathrm{RT}=25.3 \mathrm{~min}$. The insert is the MS/MS spectrum of a parent peak at $\mathrm{m} / \mathrm{z}=$ 753.8 Th with the sequence of HGTVVLTALGGILKK. The fractions from RPLC were infused into microchip via inlet A at a flow rate of $120 \mu \mathrm{L} \mathrm{h}^{-1}$ and the other conditions were same as those in Fig. 2 and 3. The identified peptides are marked by the stars.

incorporate emitter tip. All these results demonstrate that such a droplet-based microchip would be a promising alternative protocol used as a component of a highly integrated proteomics strategy.

\section{Acknowledgements}

This work was supported by NSFC (20925517, 21175028, 21105014) and SKLEAC201101.

\section{References}

1 R. Aebersold and M. Mann, Nature, 2003, 422, 198.

2 B. T. Chait, Science, 2006, 314, 65.

3 A. J. Link, J. Eng, D. M. Schieltz, E. Carmack, G. J. Mize, D. R. Morris, B. M. Garvik and J. R. Yates, Nat. Biotechnol., 1999, 17, 676.

4 L. L. Sun, J. F. Ma, X. Q. Qiao, Y. Liang, G. J. Zhu, Y. C. Shan, Z. Liang, L. H. Zhang and Y. K. Zhang, Anal. Chem., 2010, 82, 2574.

5 P. E. Michel, F. Reymond, I. L. Arnaud, J. Josserand, H. H. Girault and J. S. Rossier, Electrophoresis, 2003, 24, 3.

6 J. A. Dowell, D. C. Frost, J. Zhang and L. J. Li, Anal. Chem., 2008, 80, 6715.

7 B. F. Assiddiq, A. P. L. Snijders, P. K. Chong, P. C. Wright and M. J. Dickman, J. Proteome Res., 2008, 7, 2253.

8 M. X. Gao, C. H. Deng, W. J. Yu, Y. Zhang, P. Y. Yang and X. M. Zhang, Proteomics, 2008, 8, 939.

9 H. M. Yuan, Y. Zhou, L. H. Zhang, Z. Liang and Y. K. Zhang, J. Chromatogr., A, 2009, 1216, 7478.

10 G. W. Slysz and D. C. Schriemer, Anal. Chem., 2005, 77, 1572.

11 Y. Liu, Y. Xue, J. Ji, X. Chen, J. Kong, P. Y. Yang, H. H. Girault and B. H. Liu, Mol. Cell. Proteomics, 2007, 6, 1428-1436.

12 Y. Liu, H. J. Lu, W. Zhong, P. Y. Song, J. L. Kong, P. Y. Yang, H. H. Girault and B. H. Liu, Anal. Chem., 2006, 78, 801-808.

13 Y. Huang, W. Shan, B. H. Liu, Y. Liu, Y. H. Zhang, Y. Zhao, H. J. Lu, Y. Tang and P. Y. Yang, Lab Chip, 2006, 6, 534.

14 J. Ji, Y. H. Zhang, X. Q. Zhou, J. L. Kong, Y. Tang and B. H. Liu, Anal. Chem., 2008, 80, 2457-2463.

15 X. Z. Niu, B. Zhang, R. T. Marszalek, O. Ces, J. B. Edel, D. R. Klug and A. J. Demello, Chem. Commun., 2009, 6159.

16 J. S. Edgar, G. Milne, Y. Q. Zhao, C. P. Pabbati, D. S. Lim and D. T. Chiu, Angew. Chem., Int. Ed., 2009, 48, 2719.

17 G. M. Whitesides, Nature, 2006, 442, 368.

18 H. Song, D. L. Chen and R. F. Ismagilov, Angew. Chem., Int. Ed., 2006, 45, 7336 .

19 D. T. Chiu, R. M. Lorenz and G. Jeffries, Anal. Chem., 2009, 81, 5111.

20 D. L. Chen, W. B. Du, Y. Liu, W. S. Liu, A. Kuznetsov, F. E. Mendez, L. H. Philopson and R. F. Ismagilov, Proc. Natl. Acad. Sci. U. S. A., 2008, 105, 16843.

21 A. B. Theberge, G. Whyte, M. Frenzel, L. Figdalgo, R. C. R. Wootton and W. T. S. Huck, Chem. Commun., 2009, 6225.

22 B. Domon and R. Aebersold, Science, 2006, 312, 212.

23 P. Mitchell, Nat. Biotechnol., 2001, 19, 717.

24 D. Chatterjee, A. J. Ytterberg, S. U. Son, J. A. Loo and R. L. Garrell, Anal. Chem., 2010, 82, 2095.

25 A. R. Abate and D. A. Weitz, Lab Chip, 2011, 11, 1911.

26 Q. Li, J. Pei, P. Song and R. T. Kennedy, Anal. Chem., 2010, 82, 5260.

27 I. Shestopalov, J. D. Tice and R. F. Ismagilov, Lab Chip, 2004, 4, 316.

28 P. M. Gunther, F. Moller, T. Henkel, J. M. Kohler and G. A. Groß, Chem. Eng. Technol., 2005, 28, 520. 
29 G. W. Slysz and D. C. Schriemer, Rapid Commun. Mass Spectrom., 2003, 17, 1044.

30 K. Griebenow and A. M. Klibanov, J. Am. Chem. Soc., 1996, 118, 11695.

31 L. M. Fidalgo, G. Whyte, B. T. Ruotolo, J. L. P. Benesch, F. Stengel, C. Abell, C. V. Robinson and W. T. S. Huck, Angew. Chem., Int. Ed., 2009, 48, 3665.

32 Y. Zhu and Q. Fang, Anal. Chem., 2010, 82, 8361.
33 A. Vellaichamy, J. C. Tran, A. D. Catherman, J. E. Lee, J. F. Kellie, S. M. M. Sweet, L. Zamdborg, P. M. Thomas, D. R. Ahlf, K. R. Durbin, G. A. Valaskovic and N. L. Kelleher, Anal. Chem., 2010, 82, 1234.

34 M. T. Kachman, H. Wang, D. R. Schwartz, K. R. Cho and D. M. Lubman, Anal. Chem., 2002, 74, 1779.

35 B. Mayr, G. Holzl, K. Eder, M. R. Buchmeiser and C. G. Huber, Anal. Chem., 2002, 74, 6080 